\title{
Women in cardiology - from utopia to reality
}

Attenhofer Jost, C H ; Brunckhorst, C ; Kaufmann, U ; Valsangiacomo Büchel, Emanuela R

Posted at the Zurich Open Repository and Archive, University of Zurich

ZORA URL: https://doi.org/10.5167/uzh-90450

Journal Article

Published Version

Originally published at:

Attenhofer Jost, C H; Brunckhorst, C; Kaufmann, U; Valsangiacomo Büchel, Emanuela R (2013). Women in cardiology - from utopia to reality. Cardiovascular Medicine, (16):170-178. 


\title{
Women in cardiology - from utopia to reality
}

\author{
Christine H. Attenhofer Jost ${ }^{a}$, Corinna Brunckhorst ${ }^{b}$, Urs Kaufmann ${ }^{c}$,Emanuela R. Valsangiacomo Buechel ${ }^{d}$ \\ a Cardiovascular Centre Zurich, Klinik Im Park, Zurich, Switzerland \\ ${ }^{\mathrm{b}}$ Division of Cardiology, University Hospital of Zurich, Switzerland \\ 'Herzzentrum Berne, Switzerland \\ ${ }^{\mathrm{d}}$ Department of Cardiology, Children's University Hospital, Zurich, Switzerland
}

\begin{abstract}
Summary
In the past, female physicians, especially cardiologists, were a rarity. The first physicians were officially trained only at the end of the 19th century. In the last decades of the 20th century, the number of women in medicine increased tremendously; however, the number of female cardiologists has remained low, especially in invasive cardiology. The reasons include the invasive character of the work, workload and radiation exposure. The number of cardiologists must increase further: we need more women and men in cardiology. With excellent mentoring, part-time fellowships and part-time staff positions, as well as group practices and better prevention of radiation exposure, the percentage of women will hopefully increase in the future. The presence of women in cardiology is not an utopia but is required for better care of patients. For best care, both male and female cardiologists working together and speaking the same language are needed.

Key words: women in cardiology; radiation exposure; history of medicine; fellowships; gender; cardio$\log y$
\end{abstract}

\section{Introduction}

Nowadays, it is considered normal that women become physicians. It has not always been like that. Especially in cardiology, women have been a rarity in the past. This may come as a surprise, since women have always shown a tendency to care for hearts. The first female cardiologist might have been the mystic Hildegard von Bingen (fig. 1), who lived in the 12th century (10981179). The cardiac medication she used was named "Meluvin" and contained parsley, wine, honey and white vinegar. With Meluvin she attempted to treat the aching heart, heart failure, valvular heart disease and oedema. Hildegard von Bingen wrote several

Funding / potential competing interests: No financial support and no other potential conflict of interest relevant to this article were reported. books, including one on the development and treatment of various diseases with the title Causae et Curae. Because of these writings Hildegard von Bingen could be considered the first German female physician. Before, only a few

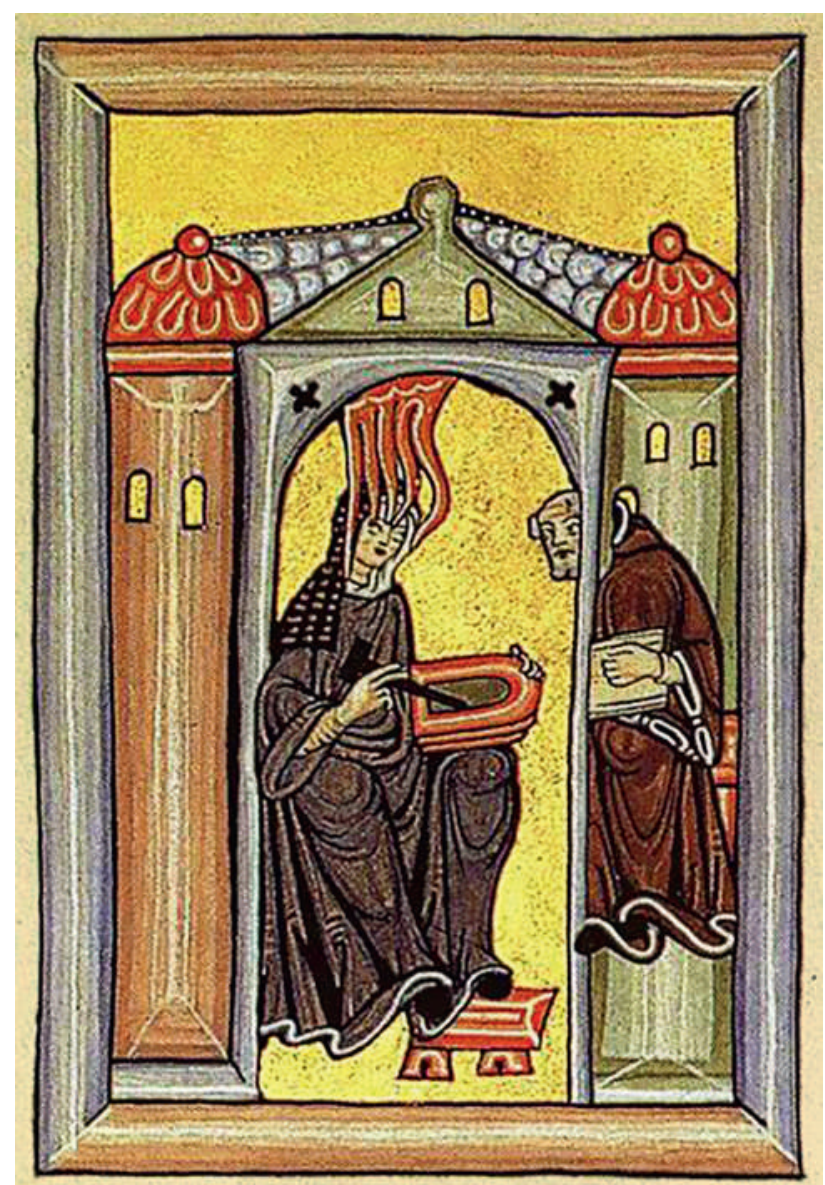

Figure 1

Hildegard von Bingen.

Miniature from the Rupertsberger Codex of Liber Scivias. Copyright: Public Domain. From Wikipedia.org.

women had been called physicians: an Egyptian, Merit Ptah (2700 BC), was mentioned in an inscription as "chief physician". She appears to be the earliest female

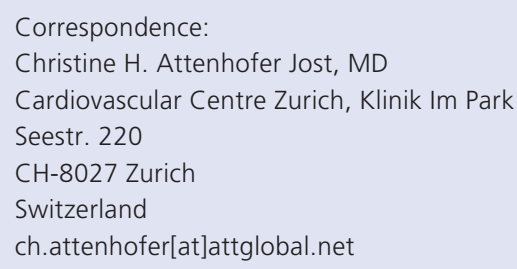




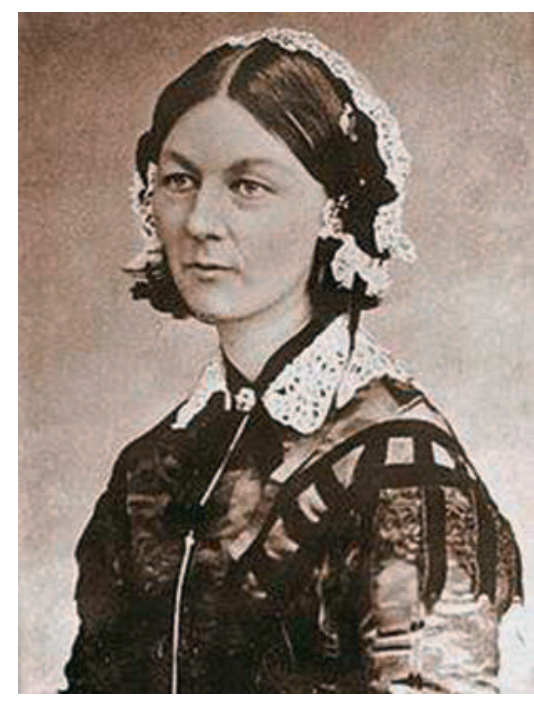

Figure 2

Florence Nightingale. From Wikipedia.org.

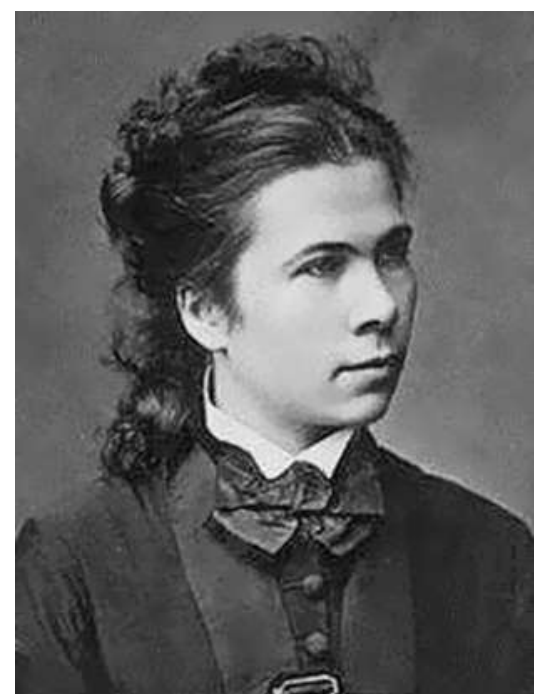

Figure 4

Nadeshda Prokofjewna Suslowa.

From Wikipedia.org

physician and female scientist named in history. Agamede (12th century BC) was cited by Homer as a healer in Greece before the Trojan War. Agnodike was the first female physician to practice legally in the 4th century BC, in Athens. Otherwise, female physicians were rare.

\section{Historical background}

Women's participation in the medical professions was limited by law and practice for many centuries. Therefore, women practiced medicine in related health fields such as nursing or midwifery. Only in the last two centuries have women made significant progress in accessing medical education and working in the medical field throughout the world. Unforgettable and famous was Florence Nightingale (1820-1910; fig. 2), who was a well-known English nurse, but also worked as a writer and statistician. She became famous during the Crimean War through her nursing work and care of

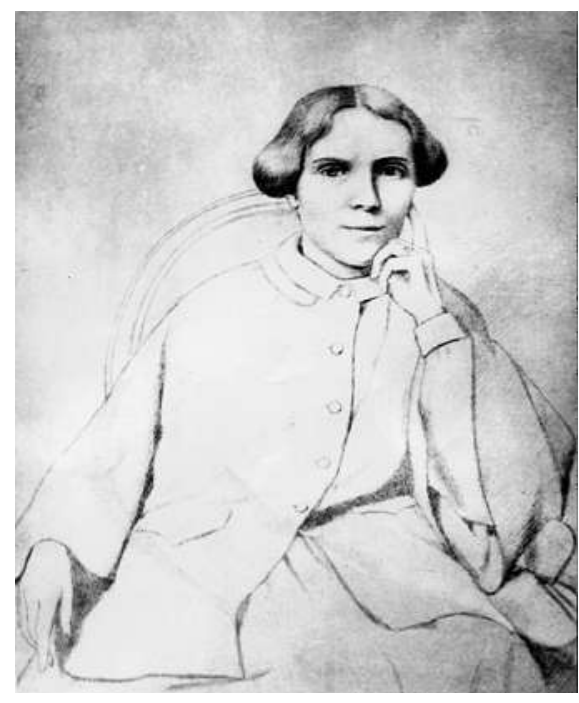

Figure 3

Elizabeth

Blackwell.

From the Geneva

Historical society.

wounded soldiers. The fiction novels of Susanne Barden, written by Helen Dore Boylston, formed our understanding of the female role in medicine for many years. These books have disappeared from the modern bookshelves and nowadays teens and young adults adore the female (and male) physicians in the TV series "ER", with Kerry Weaver and Susan Lewis. The influences of these role models may be stronger than we think.

Female university students had an awkward start. Only since 1835 has Oberlin College in Ohio accepted African Americans, and women as of 1837. Harvard opened their doors to female students in 1845. However, women were not accepted at medical schools for many more decades. It was a widespread conviction among men in the 19th century that women were intellectually and physically inferior and should therefore not practice highly responsible professions.

The first female physician in industrialised society was probably Elizabeth Blackwell (1821-1910; fig. 3). Her family moved from Great Britain to the United States. Blackwell's decision to become a doctor was influenced by the fact that she wanted to live an unattached life, independent of a man and the "chains of matrimony" (Wikipedia.org). Blackwell's decision to study medicine was made before she realised how difficult it would be to overcome the barriers to her goal.

Twenty-nine medical schools rejected Elizabeth Blackwell before she was admitted to Geneva Medical College in upstate New York in 1847. The faculty of that institution was against her application, but submitted the question to 150 male students who had to vote, with the precondition that if one student objected, Blackwell would be turned down. Either the students of the medical school assumed that the members of the faculty were joking when presenting a female application, or the students knew about the troubles of the faculty and therefore thought it would be hilarious to vote in favour of admitting the woman applicant. In 


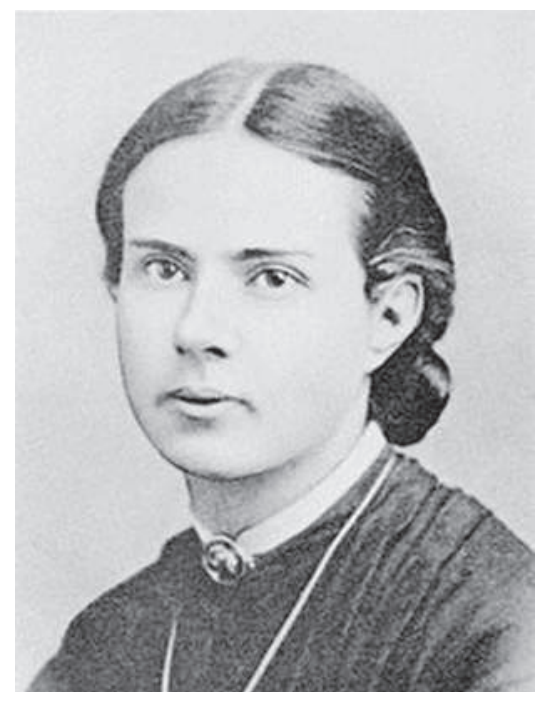

Figure 5

Marie Heim-Vögtlin. From "Eidgenössisches Büro für die Gleichstellung von Frau und Mann EBG".

any event, thanks to this vote Elizabeth Blackwell was admitted to the Geneva Medical College and graduated two years later, on 23 January 1849.

Although she was the best of her class, she was initially forbidden to practice medicine in the United States and therefore worked in London and Paris. She then founded an infirmary for women and children in 1857, and the first medical college for women in New York in 1867. The history of Elizabeth Blackwell illustrates the difficult start for women in medicine.

\section{Female Physicians in Europe}

In Europe, it was not until the second part of the 19th century that females could become physicians. The first female physician graduated in 1863 from the Sorbonne.

In Switzerland, the first female physician was the Russian Nadeshda Prokofjewna Suslowa (1843-1918; fig. 4), who completed medical training in Zurich in 1867. She was not allowed to study medicine in Russia, and as the University of Zurich at that time was considered to be very liberal, she was the first woman to be accepted at the Zurich medical school in 1866. She was very talented and became the first Russian physician and first Russian professor of medicine. On her journey to Zurich, she was accompanied by her sister Apollinarija Suslowa, the mistress of Fjodor Dostojewski. Nadeshda wrote to her family: "I am the first but not the last. After me, there will be thousands." She was right: in $1872,30 \%$ of all students in Zurich were Russian; $95 \%$ of all female students were Russians. In Switzerland, it was a sensation when the Russian, Nadeshda Suslowa, finished her medical studies.

The first 30 years of women in medicine at the University of Zurich are carefully summarised in a medical thesis by Hanny Rohner [1]. Marie Heim-Vögtlin (1845-1916; fig. 5) was the first female Swiss physician; she studed medicine at the University of Zurich, starting on 21 October 1868 and obtaining her medical degree on 11 July 1874. Today, the Swiss National Foundation promotes a grant in her memory for supporting female scientists whose career has been delayed owing to childbirth and family rearing. Marie Heim-Vögtlin had two children herself; her husband, a professor of geology, allowed her to work after her marriage. Her motivation to go into medicine might have been influenced by the fact that her previous fiancé left her for the famous Nadeshda Suslowa [2].

From 1867 until 1897, there were 13 Swiss women who graduated from medical school among 61 graduates - most came from Russia or German-speaking countries [1]. In the first half of the 20th century women doctors were still rare, but their number has increased steadily; in Switzerland in 1928, the percentage of women among graduates from medical school was $3.9 \%$; 17 years later, in 1945 , of 233 students, $14 \%$ were females.
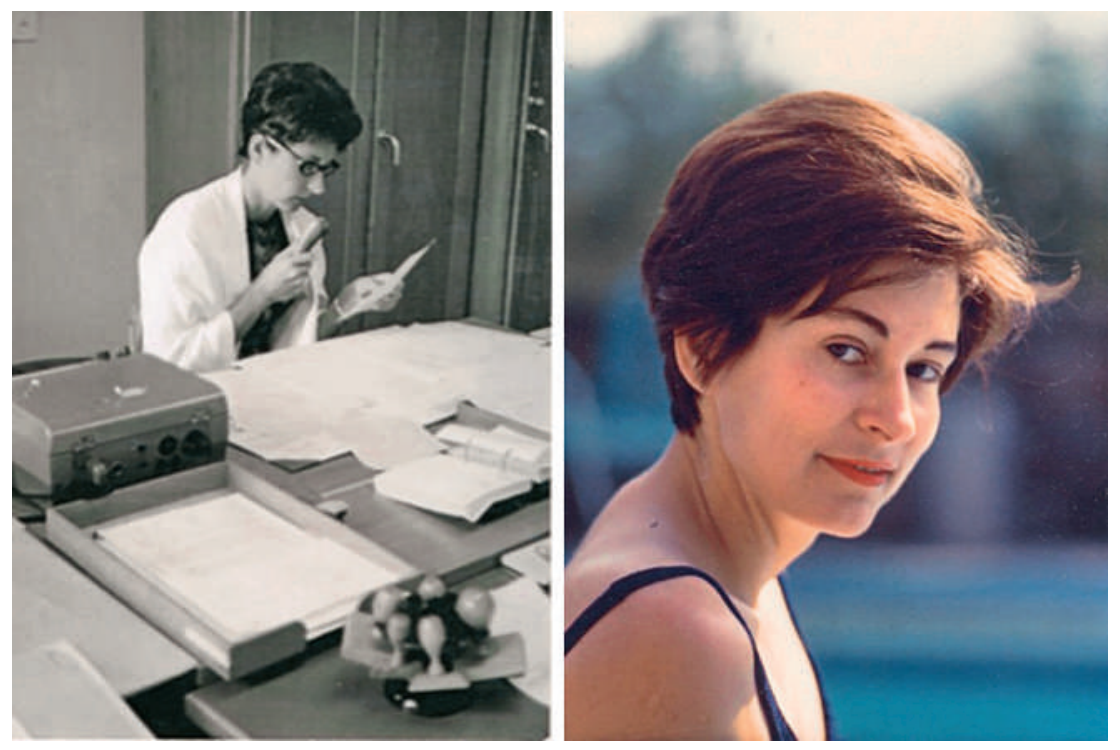

Figure 6

Ursula McKenna-Guhl.

Ursula McKenna-Guhl did her training at the University Hospital in Zurich 1959-1966,

including work in the catheter laboratory with Professor Lichtlen, then in the catheter laboratory in Vanderbilt, USA 1966/67, John Hopkins $1967 / 68$ and finally working at the Mayo Clinic 1975-1998. 


\section{Figure 7}

Isabelle Renggli at work in 1972 in the cardiac coronary care unit of the University Hospital Basel. Isabelle Renggli was on the staff at the University Hospital Basel 1970-1976 before she went into private practice, retiring in 2010

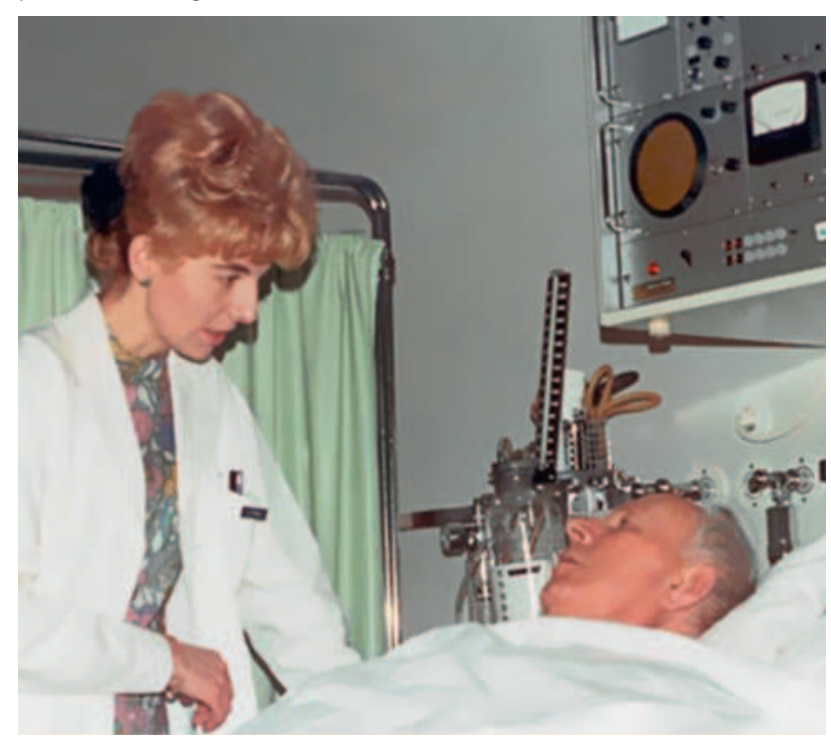

The initial problem for the integration of the female students amongst their male colleagues was nicely described by the psychiatrist August Forel in his biography in 1934: "Der natürliche Anstand, den der Mann dem Weib schuldet, zwingen die männlichen Studenten dazu, sich zusammenzunehmen und weniger lasziv, weniger pornographisch zu reden und sich $\mathrm{zu}$ benehmen; sie müssen sich in dieser Hinsicht zusammennehmen. Und das ist dem germanischen Kneipstudenten am unangenehmsten. Es ist ihm auch oft unangenehm, sich höflich Studentinnen gegenüber zu benehmen; er fühlt sich geniert - unbeholfen oder befangen. Und dies hat das Gegenteil von Liebe - d.h. eine gewisse Gereiztheit und Antipathie der Studenten, speziell der Korpsstudenten, gegen die Studentinnen hervorgerufen. Dies wird nach meiner Ueberzeugung schwinden, besonders wenn man sich an das Frauenstudium mehr gewöhnt haben wird. Je mehr normale und vernünftige Frauen studieren werden, desto mehr wird das Verhältnis freundlich und natürlich werden" [1].

Around that time cardiologists started to gain their own identity and to form societies. The American Heart Association was founded in 1924, the "Deutsche Gesellschaft für Kardiologie" in 1928. The Swiss Society of Cardiology was founded in 1948 by Pierre Duchosal (the first Swiss to receive the title cardiologist, he lived 1905-1988), Ivan Mahaim (from Belgium; 18971965) and Max Holzmann (writer of the book on clinical electrocardiography; 1899-1994). The birth of the Swiss Society of Cardiology and its first 60 years were summarised and published by Wilhelm Rutishauser, also a former president of the Swiss Society of Cardiology [3].
At that time, few female cardiologists existed worldwide. For many decades parents still told their girls: "You don't want to be a doctor, you want to marry a doctor." At least. this is what the parents of Sandra Lewis, MD, told their daughter; she is now a cardiologist and very active in the field of cardiology in the United States (Portland, Oregon) (http://www.cardiovascularbusiness.com/index.php?option=com_articles \&view=article\&id=26394: the-acc-corner-lessons-fromthe-field-a-woman-in-cardiology).

The situation started to change rapidly in the 1960 s, as the first Swiss female cardiologists were trained; these included Barbara Güller (practiced in Tacoma, WA), Ursula Guhl (now McKenna-Guhl; fig. 6), Isabelle Renggli (fig. 7), Yvonne Scholer (fig. 8), the late Sue Brand, Ingrid Oberhänsli (a paediatric cardiologist) and the late, excellent invasive cardiologist Antonia Lüthy. Barbara Güller, who was probably the first female Swiss cardiologist, trained as a paediatric cardiologist at the Mayo Clinic and had her cardiology practice in Tacoma, Washington, in the United States. Ursula McKenna-Guhl received an excellent cardiology fellowship training that included invasive cardiology in Zurich, Vanderbilt and John Hopkins, and thereafter worked at the Mayo Clinic for one year in the department of cardiology, and for many years in the emergency room as a staff physician. The first female on the cardiology staff at the Mayo Clinic was Carole Warnes who started to work there in 1987, only 25 years ago. Increasingly, female cardiologists were seen in Europe, including the famous Briton Celia Oakley, the Briton Jane Somerville (forerunner in congenital heart disease), the Italian Maria Grazia Modena (one of the first female presidents of a national cardiological society) and the Norwegian Liv Hatle, the

\section{Figure 8}

Yvonne Scholer with Professor Lichtlen (middle) and a colleague (Karl Gattiker, on the right).

Yvonne Scholer was for 5 years on staff in the catheter laboratory at the University Hospital in Zurich (1974-1979), then worked in internal medicine, before she went into private practice in 1981 and retired in 2005

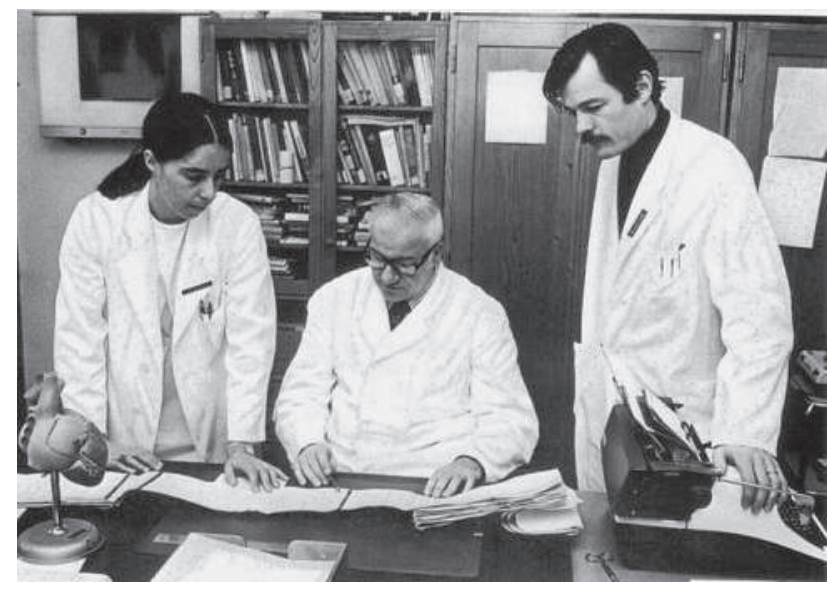


famous, excellent and unforgettable echocardiographer. Some of them became role models for the future generation of young female cardiologists.

One of the first invasive female cardiologists in Switzerland was Yvonne Scholer (fig. 8). She had been asked by the famous Professor Lichtlen, who was at that time a great supporter of women in cardiology, to join his catheter laboratory at the university hospital of Zurich. Later, Yvonne Scholer went into private practice on Bahnhofstrasse in Zurich, following the famous Professor Max Holzmann, and remained active until 2005.

In Switzerland in 2011, there were 30,849 physicians overall, according to the FMH (the Swiss Medical Association) [4]. Of these, 36.7\% were females. Only $9.6 \%$ of the heads of department were women. Seventythree percent of female physicians in 2011 were working part-time, according to a questionnaire answered by 4,561 physicians [4].

\section{Problems of cardiology specialisation}

The percentage of women in cardiology remains low compared with internal medicine and other subspecialties. In the United States in 2004, $42 \%$ of residents in internal medicine were women, but only $18 \%$ of the fel-

\section{Table 1}

Percentage of female cardiologists among physicians obtaining the cardiology specialisation title.

\begin{tabular}{|llll|}
\hline Year & Total number & $\begin{array}{l}\text { Number } \\
\text { of women }\end{array}$ & $\begin{array}{l}\text { Percentage } \\
\text { women }\end{array}$ \\
\hline $1926 / 1930$ & 0 & 0 & 0 \\
$1931 / 1935$ & 0 & 0 & 0 \\
\hline 1940 & 0 & 0 & 0 \\
\hline 1950 & 1 & 0 & 0 \\
\hline 1960 & $?$ & $?$ & $?$ \\
\hline 1970 & 5 & $?$ & $?$ \\
\hline 1980 & 13 & $?$ & $?$ \\
\hline 1990 & 15 & 1 & $7 \%$ \\
\hline 2000 & 21 & 4 & $17 \%$ \\
\hline 2001 & 20 & 3 & $15 \%$ \\
\hline 2002 & 16 & 1 & $6 \%$ \\
\hline 2003 & 11 & 2 & $18 \%$ \\
\hline 2004 & 29 & 7 & $24 \%$ \\
\hline 2005 & 21 & 2 & $10 \%$ \\
\hline 2006 & 31 & 5 & $16 \%$ \\
\hline 2007 & 21 & 2 & $10 \%$ \\
\hline 2008 & 35 & 5 & $17 \%$ \\
\hline 2009 & 32 & 7 & $22 \%$ \\
\hline 2010 & 32 & 3 & $12 \%$ \\
\hline 2011 & 45 & 9 & $20 \%$ \\
\hline & & & \\
\hline
\end{tabular}

lows in cardiology were females [5]. This is comparable to gastroenterology, pulmonary medicine, general surgery and critical care $[5,6]$. In Switzerland, the percentage of female cardiologists has increased in recent years, but remains at around 20\% (table 1), although the percentage of women obtaining a medical school diploma has increased massively (table 2). What are the reasons for this under-representation of women in cardiology? The reasons include workload, radiation exposure, especially in view of future pregnancies, the limited number of flexible part-time jobs as fellows, on staff or in private practice, the work is too invasive, and achievement syndrome [7].

\section{Workload.}

In the past, cardiology was a discipline "reserved" for physicians ready to invest a great amount of time in their training and career, which was not attractive for many, especially for women planning to have a family at some point in their lives. However, in the last decade, the distribution of family tasks between men and women has been changing rapidly, making it possible for women to plan a career effectively. There is a shift away from the traditional "lone wolf" private practice to an academic, hospital or group setting [5]. For cardiologists planning to work in a private practice, group

Table 2

Number and gender distribution of the students obtaining a medical school diploma in Switzerland.

\begin{tabular}{|c|c|c|c|}
\hline Year & $\begin{array}{l}\text { Number } \\
\text { finishing }\end{array}$ & $\begin{array}{l}\text { Number } \\
\text { of women }\end{array}$ & $\begin{array}{l}\text { Percentage } \\
\text { women }\end{array}$ \\
\hline 1926/1930 & 136 & 0 & 0 \\
\hline $1931 / 1935$ & 133 & 22 & $17 \%$ \\
\hline 1940 & 78 & 8 & $10 \%$ \\
\hline 1950 & 273 & 29 & $11 \%$ \\
\hline 1960 & 236 & 22 & $9 \%$ \\
\hline 1970 & 500 & 89 & $18 \%$ \\
\hline 1980 & 851 & 227 & $27 \%$ \\
\hline 1990 & 770 & 273 & $35 \%$ \\
\hline 2000 & 756 & 341 & $45 \%$ \\
\hline 2001 & 784 & 381 & $49 \%$ \\
\hline 2002 & 701 & 364 & $52 \%$ \\
\hline 2003 & 625 & 295 & $47 \%$ \\
\hline 2004 & 675 & 337 & $50 \%$ \\
\hline 2005 & 622 & 338 & $54 \%$ \\
\hline 2006 & 594 & 349 & $59 \%$ \\
\hline 2007 & 612 & 333 & $54 \%$ \\
\hline 2008 & 667 & 409 & $61 \%$ \\
\hline 2009 & 729 & 448 & $61 \%$ \\
\hline 2010 & 813 & 499 & $61 \%$ \\
\hline 2011 & 453 & 263 & $52 \%$ \\
\hline
\end{tabular}


solutions are obviously rapidly taking over for a number of financial, logistic and quality-of-life reasons, which hopefully will enable women to work as specialists, especially in cardiology.

\section{Invasive cardiology and radiation exposure.}

More men than women work as invasive cardiologists ( $29 \%$ vs $11 \%$ ) [5]. Of over $30 \%$ of all survey respondents who altered their training practice focus to reduce the risk of occupational radiation exposure, $84 \%$ were women [5]. Twenty-four percent of women and $5 \%$ of men chose careers/training tracks with minimal radiation exposure [5]. Invasive cardiologists have a much higher radiation exposure than the noninvasive cardiologists. Occupational radiation exposure of invasive cardiologists has been examined: the effective doses ranged from 0.02-38.0 microSievert ( $\mu \mathrm{Sv}$ ) for diagnostic catheterisations, $0.17-31.2 \mu \mathrm{Sv}$ for percutaneous coronary interventions, $0.24-9.6 \mu \mathrm{Sv}$ for ablations, and 0.29 $17.4 \mu \mathrm{Sv}$ for pacemaker or intracardiac defibrillator implantations [8]. Radiation exposure may indeed be a danger to anybody's health and alarming reports have been published [9]. However, there are no current data suggesting an increased risk to the foetus of pregnant women in the catheterisation laboratory, but it is recommended that radiation exposure of pregnant physicians should be monitored and adequate radiation safety measures are still warranted $[10,11]$. On top of the fear of radiation damage, training in invasive cardiology typically remains a demanding activity in terms of workload and physical load, and therefore has not attracted many women so far.

\section{Part-time fellowships: so far there is a shortage of part-time fellowships.}

In the requirements of the Swiss Society of Cardiology, it is stated that at least one year of the fellowship has to be full-time. Also, part-time staff positions are though there is some progress - still rare. There is no evidence suggesting that working part-time has a negative effect on professional knowledge, focus or work performance, but in many leading minds, part-time coworkers have the image of performing less. However, there is a study showing, by means of multivariate analyses, that fellowship training, mentors, academic support and number of total years worked are associated with more publications and better acquisition of funding [12]. There was no negative impact of working part time on publications or success in finding funding [12]. Trainee satisfaction is known to be better if parttime jobs are offered [13].

\section{Invasive character of cardiology.}

Women are more likely than men to describe their primary or secondary role as a clinical/noninva-sive cardiologist than an invasive cardiologist $(p<0.0001$ women

Figure 9

Examples of female cardiologists working in Switzerland in 2012.

All the cardiologists in the picture gave permission for it to be used.

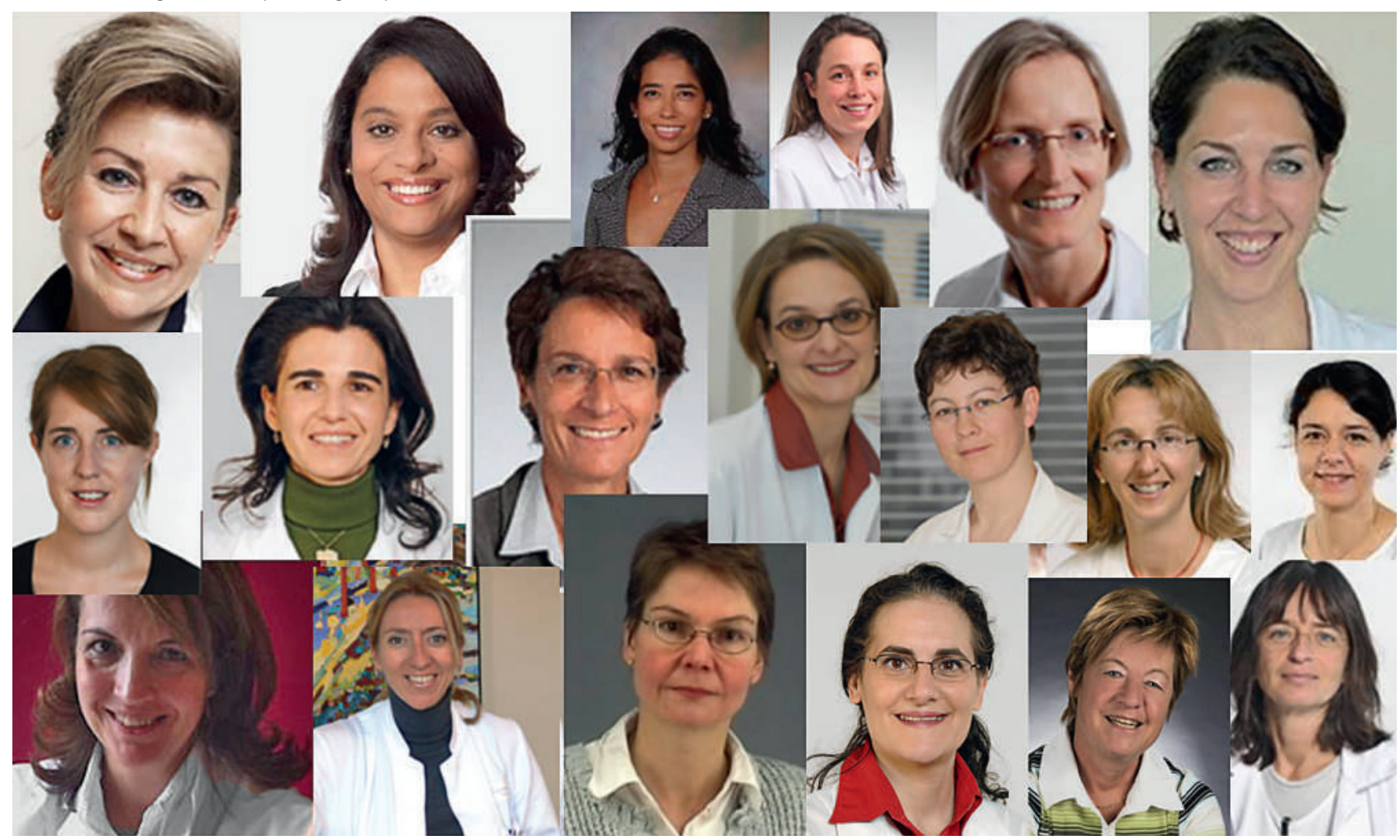




\section{Figure 10}

Examples of female cardiologists with their children.

All the cardiologists in the picture gave permission for it to be used.

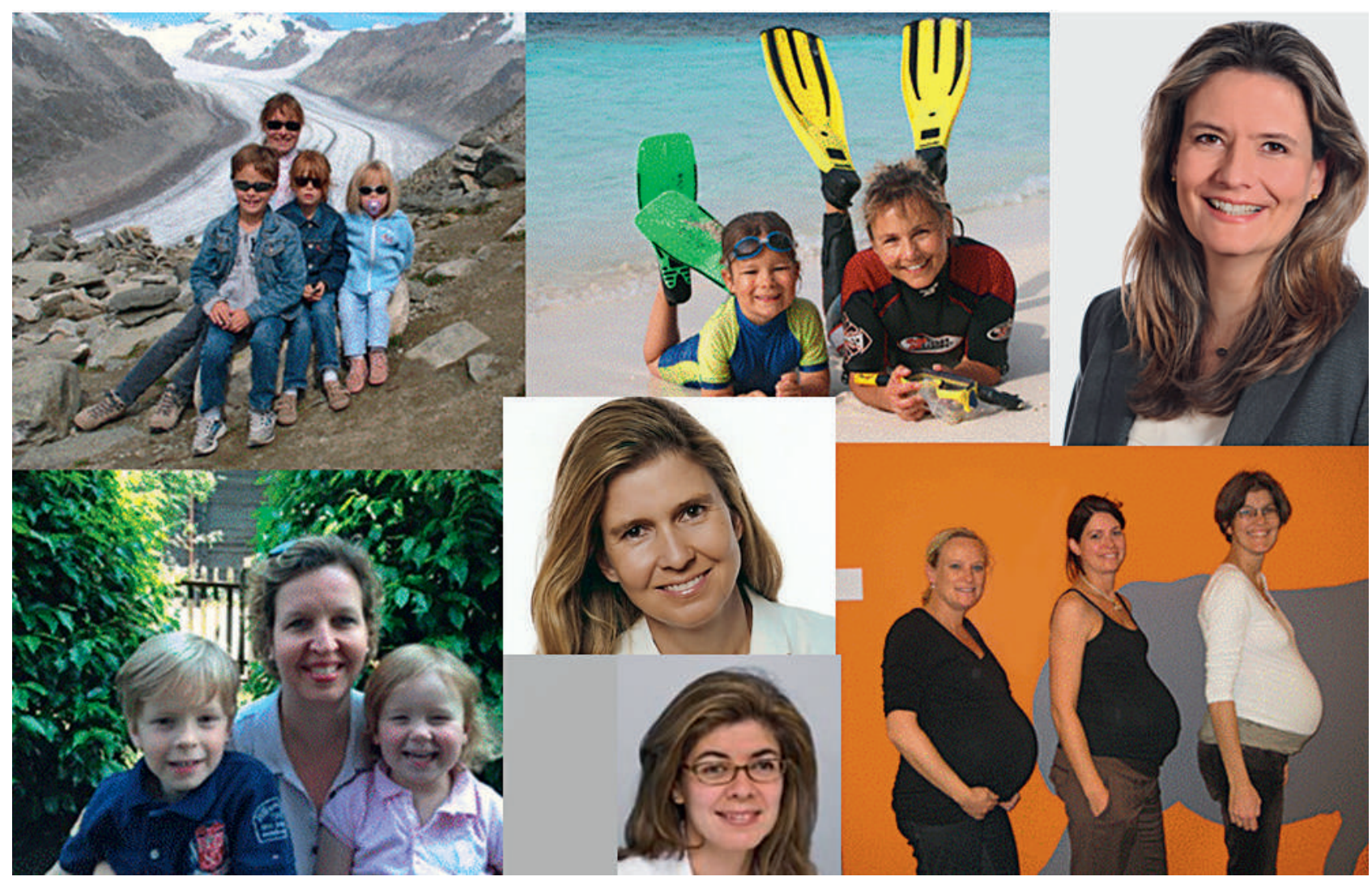

vs men) [14]. This might reflect fundamental differences between men and women in the perception of the role of a physician because invasive cardiology is not only physically demanding, but also requires a strong belief in "action" medicine, which is probably more a male than a female pattern. Therefore, the percentage of women in invasive cardiology will remain lower than in noninvasive cardiology - at least as long as there are not enough female mentors [15].

\section{Achievement syndrome.}

What is the achievement syndrome? If a woman finishing internal medicine training is unmarried or does not have a permanent partner, she may become a victim of "achievement syndrome": she wants to have children before it is too late and this brings insecurity to a potential candidate considering another $3-5$ years of training [7]. In a survey, $19 \%$ of female cardiologists were unmarried and $37 \%$ had no children; in contrast, $4 \%$ of male cardiologists were unmarried and $12 \%$ had

Table 3

Comparison of male and female attitudes affecting the integration of female physicians after Andreotti et al. [17].

$\begin{array}{ll}\text { Female } & \text { Male } \\ \text { Lack of role models } & \text { Difficulty in recognising female professional autonomy } \\ \text { Dependence on male figures } & \text { Uneasiness with female authority } \\ \text { Low self esteem } & \text { Sense of intellectual, physical and psychological superiority } \\ \text { Low level of expectations and demands } & \text { High level of ambitions and expectations } \\ \text { Undisputed role as family caretaker (children, parents) } & \text { Undisputed role as family bread winner } \\ \text { Taking on responsibility in excess of level of authority } & \text { Delegating responsibilities but not authority to female colleagues } \\ \text { Charm used for career advancement } & \text { Some degree of sexism tolerated } \\ \text { Unfounded fear of radiation } & \text { Unfounded fear of women? }\end{array}$


no children [7]. Hopefully, this will be less of a problem in the future. In a more recent survey, $73 \%$ of women and $91 \%$ of men were married [5]. Nine percent of female and $66 \%$ of male cardiologists had spouses taking care of the children.

So far, women have had to work harder and publish more to achieve the same academic success and acceptance as male colleagues. This has been demonstrated in studies showing that among candidates for a postdoctoral fellowship, women needed to have published more research papers and to be 2.5 times as productive as male peers in order to be rated as equally competent [16].

Another point of view previously published is shown in table 3 , which compares male and female attitudes affecting the integration of female physicians (after Andreotti et al. [17]). This table does have some feminist aspects, but there is a little bit of truth in it.

If women do decide to become cardiologists, what is their professional satisfaction? There was a survey among female and male cardiologists made by the American College of Cardiology, and published in 1998 [14]. Women described less satisfaction (69\%) than men $(84 \%)$ and more dissatisfaction with their ability to achieve their professional goals ( $21 \%$ vs $9 \%$ ). At that time, $71 \%$ of women reported gender discrimination. In addition, they often changed training to avoid radiation [14].

Interestingly enough, more women in paediatrics choose cardiology than their counterparts in internal medicine [18]. In Switzerland also, women in paediatric cardiology have had more success regarding academic achievement and becoming chief of cardiology than those in adult cardiology. This may reflect the generally higher percentage of female residents and fellows in paediatric medicine. More recently, the increasing numbers of female doctors in various disciplines, such as paediatrics and gynaecology/obstetrics, has brought about a change of institutional culture, such that having a family and children is considered the normal rule and not an exception; in addition, in these disciplines the chance of part-time work/jobsharing is increasingly being offered.

\section{Situation in cardiology in Switzerland in 2012}

Today there is an increasing number of successful women cardiologists; you can recognise a few in fig. 9 . Figure 10 shows a few successful women cardiogists from Switzerland who have children. However, in leading positions the situation is still not satisfactory. Of 207 cardiologists in leading or permanent positions at 41 centres in Switzerland in 2012, only 26 are women (11\%). Female invasive cardiologists are rare. There is no female chief of cardiology. In the Swiss Society of Cardiology Board, so far only one woman has been an ordinary member (since 2006). In 2011, the FMH reg- istered a total of 76 women cardiologists (15.2\%) and 498 male cardiologists. Overall, in 2011 in Switzerland, there were 30,849 physicians, and $36.7 \%$ of these were females.

However, the number of women in the medical schools has increased considerably in recent decades. In 1975 , less than $15 \%$ of students entering US medical schools were women; in contrast, in $2005,51 \%$ of incoming medical students were women [7]. In Switzerland, as mentioned before, the percentage of women has increased. It was 3.9\% in 1928 and in 2011, 569 students matriculated at the University of Zurich in the department of medicine, including doctorates; 300 of these students were females $(53 \%)$. However, only $18 \%$ of all physicians achieving habilitations are women.

This situation is even worse in other European countries: in the United Kingdom, for example, only $8 \%$ of appointed registrars in cardiology are women [19].

A female touch in cardiology is as good as in other fields of medicine: as described by Cousin and Schmid Mast, compared with their male counterparts female physicians communicate differently with patients, with more empathy and more information on the psychosocial aspects [20]. In 2001, Buddeberg-Fischer et al. conducted a study on the personality traits, career motivation and career planning of 719 graduate students of medicine [21]. Male students scored higher on independence, decisiveness, self-confidence, activity, income and prestige; men preferred to specialise more in instrument-oriented and high-technology medicine; in contrast, women were more advanced in writing their theses and preferred fields with intensive patient contact. Another study has shown that empathy is less pronounced in medical students choosing technologyoriented specialties [22]. So more female physicians in cardiology might result in more physicians performing interventional cardiology in combination with more empathy.

\section{The future}

We need more cardiologists. People want to stay fit longer; there are more percutaneous interventions; there is the increasing age of the population; there are more survivors of coronary artery disease, congenital heart disease and valvular heart disease. But old ideas (the "male" field feeling and profiling, isolated private practice, workload and distribution of tasks between married partners) are rapidly changing and make it clear that cardiologists need to promote female physicians in cardiology. We need more of both male and female cardiologists and need to advertise and offer attractive fellowships. To increase the attractivness of the cardiology fellowship programmes, cardiology chiefs have to offer part-time jobs with the option to finish cardiology. Even (or especially!) if academic medicine is the goal, 
this can be done very well. We also have to fight for our income and for the options of group practices. Sexistbehaviour has to be controlled, and, last but not least, excellent mentoring must be offered. The first mentor in history was a woman. In Homer's tale the goddess Athena motivated the young Telemachus, son of Odysseus, and educated him through guidance and self-discipline. So we need mentors, both men and women, to guide and stimulate young physicians along their professional careers.

Elizabeth Blackwell said: "Medicine ... must be regarded as one of those great departments of work in which the cooperation of men and women is needed to fulfil all its requirements." Therefore, in any field of work, and particularly in medicine, men and women need to collaborate to achieve the best for the patient. In cardiology this is not utopia, but the future.

\section{References}

1 Rohner H. Die ersten 30 Jahres des medizinischen Frauenstudiums an der Universität Zürich 1867-1897. Medizinische Fakultät der Universität Zürich; 1972. German.

2 Müller VE. Marie Heim-Vögtlin - die erste Schweizer Ärztin (18451916). Ein Leben zwischen Tradition und Aufbruch. Baden: Hier und Jetzt Verlag; 2007. German.

3 Rutishauser W. 60 Jahre Schweizer Gesellschaft für Kardiologie 19482008. Basel: EMH Schweizerischer Aerzteverlag AG; 2008. German.

4 Kraft E. FMH-Aerztestatistik 2011. 30849 Aerztinnen und Aerzte für die Schweiz. Schweizerische Aerztezeitung. 2012;93. German.

5 Poppas A, Cummings J, Dorbala S, Douglas PS, Foster E, Limacher MC. Survey results: a decade of change in professional life in cardiology: a 2008 report of the ACC women in cardiology council. J Am Coll Cardiol. 2008;52(25):2215-26.

6 Graduate medical education. JAMA. 2005;294(9):1129-43.

7 Saxon LA, Rao AK, Klarich KW. Shortage of female cardiologists: exploring the issues. Mayo Clin Proc. 2008;83(9):1022-5.

8 Kim KP, Miller DL, Balter S, Kleinerman RA, Linet MS, Kwon D, et al Occupational radiation doses to operators performing cardiac catheterization procedures. Health Phys. 2008;94(3):211-27.
9 Roguin A, Goldstein J, Bar O. Brain malignancies and ionising radiation: more cases reported. EuroIntervention. 2012;8(1):169-70.

10 Best PJ, Skelding KA, Mehran R, Chieffo A, Kunadian V, Madan M, et al. SCAI consensus document on occupational radiation exposure to the pregnant cardiologist and technical personnel. Heart Lung Circ. 2011; 20(2):83-90.

11 Best PJ, Skelding KA, Mehran R, Chieffo A, Kunadian V, Madan M, et al. SCAI consensus document on occupational radiation exposure to the pregnant cardiologist and technical personnel. EuroIntervention. 2011; 6(7):866-74.

12 Levine RB, Mechaber HF, Bass EB, Wright SM. The impact of working part-time on measures of academic productivity among general internists. J Womens Health (Larchmt). 2010;19(11):1995-2000.

13 von Websky MW, Oberkofler CE, Rufibach K, Raptis DA, Lehmann K, Hahnloser D, et al. Trainee satisfaction in surgery residency programs: Modern management tools ensure trainee motivation and success. Surgery. 2012;152(5):794-801.

14 Limacher MC, Zaher CA, Walsh MN, Wolf WJ, Douglas PS, Schwartz JB, et al. The ACC professional life survey: career decisions of women and men in cardiology. A report of the Committee on Women in Cardiology, American College of Cardiology. J Am Coll Cardiol. 1998;32(3): 827-35.

15 Nee LM. Dawn out of the darkness. JACC Cardiovasc Interv. 2011; $4(1): 131$.

16 Gannon F, Quirk S, Guest S. Searching for discrimination. Are women treated fairly in the EMBO postdoctoral fellowship scheme? EMBO Rep. 2001;2(8):655-7.

17 Andreotti F, Crea F. Women in cardiology: a European perspective. Heart. 2005;91(3):275-6.

18 Warnes CA, Fedson SE, Foster E, Jessup M, Limacher MC, O’Donnell JA, et al. Working group 2: How to encourage more women to choose a career in cardiology. J Am Coll Cardiol. 2004;44(2):238-41.

19 Timmis AD, Baker C, Banerjee S, Calver AL, Dornhorst A, English KM, et al. Women in UK cardiology: report of a Working Group of the British Cardiac Society. Heart. 2005;91(3):283-9.

20 Cousin G, Schmid Mast M. Les médecins hommes et femmes interagissent de manière différente avec leurs patients: pourquoi s'en préoccuper? Rev Med Suisse. 2010;6(257):1444-7.

21 Buddeberg-Fischer B, Klaghofer R, Abel T, Buddeberg C. The influence of gender and personality traits on the career planning of Swiss medical students. Swiss Med Wkly. 2003;133(39-40):535-40.

22 Tavakol S, Dennick R, Tavakol M. Empathy in UK medical students: differences by gender, medical year and specialty interest. Educ Prim Care. 2011;22(5):297-303. 